\title{
Seroprevalence of Toxoplasma gondii in HIV-infected patients admitted to a university hospital
}

\author{
Bir üniversite hastanesine başvuran HIV ile enfekte hastalarda Toxoplasma \\ gondii seroprevalansı
}

\author{
@Pınar Ergen, @Fatma Yılmaz Karadağ, @Özlem Aydın \\ ${ }^{1}$ Medeniyet Üniversitesi Göztepe Eğitim ve Araştırma Hastanesi, Enfeksiyon Hastalıkları ve Klinik Mikrobiyoloji, İstanbul, Türkiye
}

Cite this article as/Bu makaleye atıf için: Ergen P, Yılmaz Karadağ F, Aydın Ö. Seroprevalence of Toxoplasma gondii in HIV-infected patients admitted to a university hospital. J Health Sci Med 2020; 3(4): 372-376.

\begin{abstract}
Objective: Toxoplasma gondii may lead to opportunistic infections that threaten life in patients infected with HIV as opposed to the case of healthy individuals. It was aimed to investigate the seroprevalence of Toxoplasma gondii in HIV-infected patients admitted to our clinic.

Material and Method: The files of HIV-infected patients who were admitted to our polyclinic in the period of January 1995-December 2019 were examined. From the files, information was recorded on demographic characteristics, first diagnosis date, CD4+ T lymphocyte counts at first admission, HIV RNA, T. gondii IgG/M values and whether or not they received antibiotic prophylaxis.

Findings: Although the files of $804 \mathrm{HIV}$-infected patients were examined, data on T. gondii antibodies could be accessed only in the files of 685 patients. The median values of the ages and disease durations of the patients were respectively 33 (range: 17-83) and 4 (range $0-27$ ) years. Among the patients, $88.5 \%$ (n: 606) were male. While no patients showed T. gondii IgM antibody positivity, 41.6\% (n:285) had T. gondii IgG positivity. The CD4+ T lymphocyte count was under 100 in $10.0 \%$ (n: 68/678) of the patients, and among 36.8\% (n: 25/68) of these patients, T. gondii IgG was positive. While T. gondii IgG positivity was significant in the patients over the age of 40 and those who were diagnosed before 2010 , no significant relationship was found between sex, being men who have sex with men or not, CD4+ T lymphocyte counts and HIV-RNA values.

Conclusion: In patients with $T$. gondii IgG positivity, the risk of toxoplasmosis reactivation increases especially when the CD4+ T lymphocyte counts fall below 200. For this reason, investigating the seroprevalence of $T$. gondii in patients of all ages is important to be able to assess the risks that may develop, and it should be kept in mind that seropositivity may increase by advanced age.
\end{abstract}

Keywords: Toxoplasmosis, HIV, seroprevalence

\section{ÖZ}

Amaç: Toxoplasma gondii, sağlıklı bireylerin aksine HIV ile enfekte hastalarda hayatı tehdit eden firsatçı enfeksiyonlara neden olabilmektedir. Kliniğimize başvuran HIV ile enfekte hastalarda Toxoplasma gondii seroprevalans araştırılması amaçlandi.

Gereç ve Yöntem: Ocak 1995-Aralık 2019 tarihleri arasında polikliniğimize başvuran, HIV ile enfekte hastaların dosyaları incelendi. Dosyalardan demografik bilgiler, ilk tanı tarihi, ilk başvurduklarında ölçülen CD4+ T lenfosit sayısı, HIV RNA, T. gondii IgG/M değerleri ve antibiyotik profilaksisi alıp almadıkları kayıt edildi.

Bulgular: HIV ile enfekte 804 hasta dosyası incelenmesine rağmen, sadece 685 hasta dosyasında T. gondii antikor verilerine ulaşılabildi. Hastaların yaş ve hastalık sürelerinin ortanca değerleri sırasıyla 33 (yaş aralığı: 17-83) ve 4 (yıl aralığı 0-27) yıldı. Çalışmaya katılanların \%88,5' i (n:606) erkek hasta idi. Hastaların hiçbirinde T. gondii IgM antikor pozitifliği saptanmazken \%41,6 (n: 285) 'da T. gondii IgG pozitifliği saptandı. Hastaların \%10,0'unda (n: 68/678) CD4+ T lenfosit sayısı 100 altındaydı ve bunların \%36,8 'inde (n: 25/68) T. gondii IgG pozitifti. T. gondii IgG pozitifliği istatistiksel olarak 40 yaş üzeri ve 2010 yılından önce tanı alan hastalarda anlamlı bulunurken cinsiyet, erkeklerle seks yapan erkek olup olmama, CD4+ T lenfosit sayısı ve HIV RNA değerleri ile arasında istatistiksel olarak ilişki saptanmadı.

Sonuç: T. gondii IgG pozitif olan hastalarda özellikle CD4+ T lenfosit sayısı 200’ün altına düştüğünde toksoplazmoz reaktivasyonu gelişme riski artmaktadır. Bu nedenle her yaştaki hastada T. gondii seroprevalansının araştırılması gelişebilecek riskleri değerlendirebilmek için önemli olup, ilerleyen yaşla birlikte seropozitifliğin artabileceği unutulmamalıdır.

Anahtar kelimeler: Toksoplazmoz, HIV, seroprevalans 


\section{INTRODUCTION}

Toxoplasmosis is a zoonotic infection caused by Toxoplasma gondii, which is an obligate intracellular parasite. While the disease may develop as a result of contact with cat excrements or raw or undercooked consumption of foods contaminated with excrements, it may also be transmitted through the vertical path from the mother to the fetus in pregnancy. It was also reported to develop in the form of organ transplantation and laboratory accidents (1-3).

It is estimated that a third of the world's population are infected with toxoplasma (4). Although the disease usually progresses asymptomatically in adults and healthy children, it may lead to life-threatening conditions in immunosuppressed individuals.

In patients whose immune system is suppressed by the human immunodeficiency virus (HIV), toxoplasmosis may appear as an opportunistic infection According to the 2018 data of the World Health Organization (WHO), 37.9 million HIV-infected individuals are living in the world, and 23.3 million individuals received antiretroviral treatment by the end of 2018 (5). While the risk of encountering opportunistic infections is reduced by highly active antiretroviral therapy (HAART), toxoplasmosis continues to be a significant problem for HIV/ AIDS (Acquired Immune Deficiency Syndrome) patients $(4,6)$. One of the risk factors for development of toxoplasmic encephalitis is a CD4+ T lymphocyte count of under $100 / \mathrm{mm} 3$ (7).

There are few studies in Turkey which investigated the seroprevalence of toxoplasmosis in HIV-infected patients. In this study, our purpose is to determine the toxoplasma seroprevalences of patients with a diagnosis of HIV/ AIDS who were admitted to our polyclinic at their first admission and to closely monitor patients in terms of latent infection reactivation and primary toxoplasmosis that may develop especially in patients with low CD4+ T lymphocyte counts.

\section{MATERIAL AND METHOD}

This study was approved by the university/local human research ethicscommittee and all procedures performed in studies involving human participants were in accordance with the ethical standards of the institutional and/or national research committee and with the 1964 Helsinki Declaration and its later amendments or comparable ethical standards. The study was carried out with the permission of Medeniyet University Göztepe Education and Research Hospital Ethics Committee. (Permission granted 20.11.2019, Decision No. 2019/0466).
The files of patients who were admitted to our polyclinic for the first time in the period of January 1995-December 2019 whose HIV positivity was confirmed by Western Blot test were examined. From the patient files, information was retrospectively collected on demographic characteristics, date of first diagnosis, CD4+ T lymphocyte count measured at first admission to the polyclinic, HIV RNA viral load, T. gondii IgG and IgM values and whether or not they received trimethoprimsulfamethoxazole (TMP-SMX) prophylaxis.

T. gondii IgG and M studied with the ELISA method, CD4+ T lymphocyte counts studied with the flow cytometric method and HIV RNA values measured by the PCR method were determined and recorded. The files of 804 HIV-infected patients could be accessed, but 119 patients whose T. gondii data could not be reached were removed from the study, and only 685 patients were included in the analysis. The relationship between patients age, sex, period when HIV was diagnosed, being men who have sex with men (MSM) or not, CD4+ T lymphocyte counts and HIV RNA values during first application, and T. gondii seroprevalence was evaluated statistically.

Statistical analyses were carried out using the SPSS IBM 22,0 (SPSS Inc, Chicago II) software. The descriptive results of the categorical variables are shown as frequency distributions and percentages. The data not conforming to normal distribution are expressed as median (minimum-maximum). While the categorical variables were analyzed, chi-squared or Fisher's exact test was used.

\section{RESULTS}

In the study, the data of 685 patients, including 606 (88.5\%) male and $79(11.5 \%)$ female patients, were analyzed. Among the male patients, $57.6 \%$ (n: 349 ) were MSM (men who have sex with men). The median values of the ages and disease durations of the patients were respectively 33 (range: 17-83) and 4 (range: $0-27$ ) years. The demographic data and T. gondii IgG antibodies of the patients are shown in Table 1. 285 (41.6\%) of the patients showed T. gondii IgG seropositivity. 68 (10.0\%) patients had CD4+ T lymphocyte counts of lower than 100 cells/ $\mathrm{mm}^{3}$, while $25(36.8 \%)$ of these patients were positive for T. gondii IgG. Median value of CD4 + T lymphocyte counts was 371 (range: 0-1860), median value of HIV RNA was $205.387 \mathrm{IU} / \mathrm{ml}$ (range: 2 -198.700.180). Table 2 shows the Toxoplasma antibody distribution by $\mathrm{CD} 4+$ T lymphocyte counts and HIV RNA levels.

The earliest diagnosis of the disease was made in 1992, and the toxoplasma antibody distribution in the infected patients based on years is shown in Figure 1. 
Table 1. Distribution of patients according to demographic features

\begin{tabular}{|c|c|c|c|}
\hline & $\begin{array}{l}\text { T. gondii IgG } \\
\text { positive } \mathbf{n}(\%)\end{array}$ & $\begin{array}{c}\text { T. gondii IgG } \\
\text { negative } \mathbf{n}(\%)\end{array}$ & Total $\mathbf{n}$ \\
\hline \multicolumn{4}{|l|}{ Gender } \\
\hline Woman & $37(46.8)$ & $42(53.2)$ & 79 \\
\hline Male & $248(40.9)$ & $358(59.1)$ & 606 \\
\hline \multicolumn{4}{|l|}{ Age } \\
\hline $18-40$ & $179(36.2)$ & $315(63.8)$ & 494 \\
\hline $41-60$ & $85(54.5)$ & $71(45.5)$ & 156 \\
\hline 61 and above & $21(61.8)$ & $13(38.2)$ & 34 \\
\hline \multicolumn{4}{|c|}{ Education Level (n:351) } \\
\hline University & $85(36.6)$ & $147(63.4)$ & 232 \\
\hline $\begin{array}{l}\text { Below university } \\
\text { level }\end{array}$ & $46(38.7)$ & $73(61.3)$ & 119 \\
\hline \multicolumn{4}{|l|}{ Contamination path } \\
\hline $\begin{array}{l}\text { Heterosexual } \\
\text { relationship }\end{array}$ & $126(46.0)$ & $148(54.0)$ & 274 \\
\hline $\begin{array}{l}\text { Homosexual } \\
\text { relationship }\end{array}$ & $127(36.4)$ & $222(63.6)$ & 349 \\
\hline Unknown & $32(51.6)$ & $30(48.4)$ & 62 \\
\hline \multicolumn{4}{|l|}{ Diagnostic History } \\
\hline $1992-2000$ & $10(58.8)$ & $7(41.2)$ & 17 \\
\hline 2001-2009 & $42(58.3)$ & $30(41.7)$ & 72 \\
\hline 2010-2019 & $233(39.1)$ & $363(60.9)$ & 596 \\
\hline
\end{tabular}

Table 2. Toxoplasma antibody distribution by CD $4+\mathrm{T}$ lymphocyte counts and HIV RNA levels

\begin{tabular}{|lcc|}
\hline & $\begin{array}{r}\text { T. gondii Ig G } \\
\text { positive n (\%) }\end{array}$ & $\begin{array}{c}\text { T. gondii Ig G } \\
\text { negative n (\%) }\end{array}$ \\
\hline CD4 + T Lymphocyte Counts (n:678) & \\
$<100$ (n: 68) & $25(36.8)$ & $43(63.2)$ \\
$100-200$ (n: 79) & $29(36.7)$ & $50(63.3)$ \\
$201-500$ (n: 334) & $151(45.2)$ & $183(54.8)$ \\
500 üzeri (n: 197) & $76(38.6)$ & $121(61.4)$ \\
HIV RNA levels (n: 613) & & \\
$<10.000$ (n:55) & $25(45.5)$ & $30(54.5)$ \\
$10.000-100.000$ (n:166) & $58(34.9)$ & $108(65.1)$ \\
$100.001-100000$ (n:281) & $119(42.3)$ & $162(57.7)$ \\
$>1.000 .000$ (n:111) & $43(38.7)$ & $68(61.3)$ \\
\hline
\end{tabular}

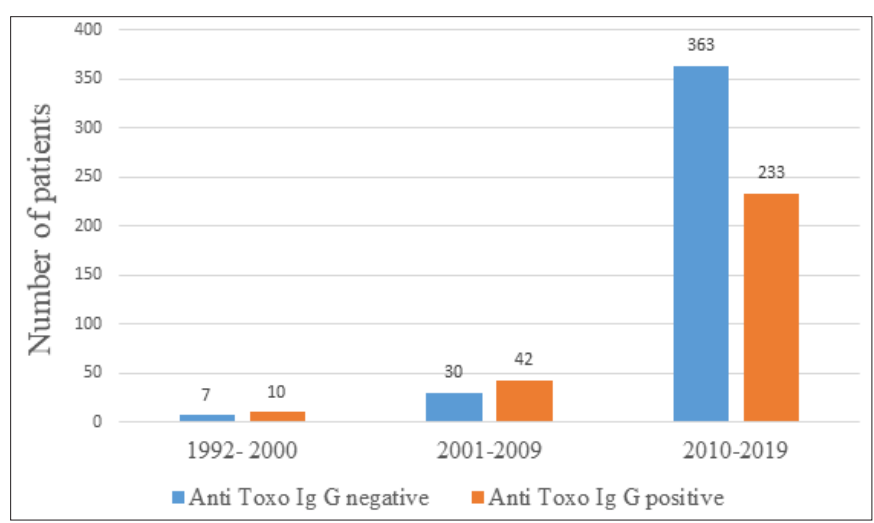

Figure 1. Toxoplasma antibody distribution in infected patients by years
T. gondii IgG positivity was significant in the patients over the age of $40 \quad(\mathrm{p}<0.001)$, while there was no significant relationship between sex $(\mathrm{p}=0.316)$ and $\mathrm{CD} 4+\mathrm{T}$ lymphocyte counts $(\mathrm{p}=0.177)$, being MSM or not $(\mathrm{p}=0.034)$, HIV RNA values $(\mathrm{p}=0.366)$. T.gondii IgG positivity within patients who diagnosed before 2010 and T.gondii IgG negativity within patients who diagnosed after 2010 were significantly higher. $(p=0.003)$

\section{DISCUSSION}

In the diagnosis of toxoplasmosis, investigation of IgGtype antibodies is a commonly used method. It is used in following immunosuppressive patients such as a HIV/AIDS and pregnant women (4). In two different studies investigating the seroprevalence of $T$. gondii IgG in HIV-infected patients in Turkey, respectively 614 and 164 patients were examined, and the rates were reported respectively as $43.5 \%$ and $52 \%(8,9)$. In studies conducted in other countries, T. gondii IgG rates were determined as $21.1 \%$ in Iran, $9.7 \%$ in China, $13.6 \%$ in the USA, $57.6 \%$ in Ghana, $36.3 \%$ in Thailand and $80 \%$ in Brazil (10-15). In the meta-analysis conducted by Safarpour et al. (16) including 37 countries, 111 studies and 66,139 serum samples, the seroprevalence of T. gondii IgG was found as $44.22 \%$. The T. gondii IgG positivity in our study was detected as $41.6 \%$, which was similar to the results of previous studies in Turkey and the metaanalysis of Safarpour et al. (16). Seroprevalence rates may vary from country to country and based on ethnic and cultural structure, nutritional habits, education levels and socioeconomic levels.

In our study, the IgG positivity within patients older than 40 and patients who diagnosed before 2010 was found significantly higher. The reason why IgG positivity is seen more in patients older than 40 is attributed to the increasing risk of exposure to infectious agents as age increases. It is thought that seronegativity is increased with increase in drinking safe water, increase in public awareness of the risks of eating raw meat and the infections that may develop with it and change in our feeding habits. The meaningful increase in seronegativity in patients who diagnosed after 2010 brings risk of development of acute infections in patients. It is important to prevent the reactivation of latent infection in seropositive patients, as well as to take the necessary precautions to prevent the disease in seronegative patients.

In our study, unlike the study made by Şenoğlu and their friends in 2018, we didn't find any meaningful difference in IgG positivity within patients who are MSM. (8) Also there wasn't any significant difference between men and women as well as between HIV RNA levels and CD4+ lymphocyte levels. 
In HIV-infected individuals, T. gondii most typically and prevalently involves the central nervous system and causes toxoplasmic encephalitis, while it may also lead to chorioretinitis, pneumonia, myocarditis, hepatitis, pancreatitis and septic shock-like clinical pictures. Toxoplasmic encephalitis, which emerges as the reactivation of latent infection, may progress fatally in HIV-infected patients $(4,17,18)$. None of these presentations have been encountered in patients who have been followed in our clinic since 1995.

In HIV/AIDS-diagnosed patients with a CD4+ T lymphocyte count of under 200 cells $/ \mathrm{mm}^{3}$, accompanying history of cancer chemotherapy and those who have been using rituximab-like biological agents or longterm steroid treatments, it is recommended to provide prophylactic antibiotics therapy to prevent opportunistic infections $(16,19)$.

Primary antibiotic prophylaxis is used to protect patients with both negative and positive T. gondii serology. In the application of prophylaxis, TMP-SMX is the firstly preferred agent (20). As an alternative treatment to TMPSMX, dapsone or pyrimethamine in T. gondii IgG negative patients and atovaquone, dapsone + pyrimethamine + folinic acid or atovaquone + pyrimethamine + folinic acid in positive patients are recommended $(19,20)$. Prophylactic antibiotics usage may be stopped in patients with CD4+ T lymphocyte counts of higher than 100 cells $/ \mathrm{mm}^{3}$ for at least three months and undetectable HIV RNA levels (19). With the start of HAART usage, a reduction was observed in opportunistic infections like toxoplasmic encephalitis by the decrease in the HIV viral load and the increase in the CD4+ lymphocyte counts. A randomized controlled study showed that there was no increase in the risk of toxoplasmic encephalitis development despite stopping prophylaxis (21). In a study in Denmark including $6325 \mathrm{HIV}$-infected patients in the pre-HAART (1995-1996) and HAART (1997-2014) periods, it was reported that, despite the start of HAART usage, toxoplasmic encephalitis may still be a cause of mortality and morbidity, but neurological sequalae and mortality considerably decrease by treatment (22).

In this study, 160/800mg TMP-SMX per day treatment was started in all patients with $\mathrm{CD} 4+\mathrm{T}$ lymphocyte counts lower than $200 \mathrm{cells} / \mathrm{mm}^{3}$. Latent toxoplasma reactivation or toxoplasmic encephalitis cases were not observed during the follow up of the patients.

\section{CONCLUSION}

HIV-infected patients with T. gondii IgG negativity should be provided information regarding protection from consumption of infected meats and contaminated foods and contact with infected animal excrements, prophylactic antibiotics should be applied on all patients with CD4+ T lymphocyte counts of lower than 200 cells/ $\mathrm{mm}^{3}$, and antibody screening should be performed to assess the risk of toxoplasmosis that usually emerges as the reactivation of latent infection.

\section{ETHICAL CONSIDERATIONS}

Ethics Committee Approval: The study was carried out with the permission of Medeniyet University Göztepe Education and Research Hospital Ethics Committee. (Permission granted 20.11.2019, Decision No. 2019/0466).

Informed Consent: Because the study was designed retrospectively, no written informed consent form was obtained from patients.

Status of Peer-review: Externally peer-reviewed.

Conflict of Interest Statement: The authors have no conflicts of interest to declare.

Financial Disclosure: The authors declared that this study has received no financial support.

Author Contributions: All of the authors declare that they have all participated in the design, execution, and analysis of the paper, and that they have approved the final version.

\section{REFERENCES}

1. Kochanowsky JA, Koshy AA. Toxoplasmagondii. CurrBiol 2018; 28: $770-1$.

2. Sukthana Y. Toxoplasmosis: beyond animals to humans. Trends Parasitol 2006; 22: 246.

3. Nissapatorn V. Toxoplasma gondii and HIV: a never-ending story. Lancet HIV 2017; 4: 146-7.

4. Montoya JG, Liesenfeld O. Toxoplasmosis. Lancet 2004; 363: 1965-76.

5. WHO. HIV/AIDS Data and statistics. (https: //www.who.int/hiv/ data/en/) Erişim Tarihi 08.01.2020

6. Saadatnia G, Golkar M. A review on human toxoplasmosis. Scand J Infect Dis 2012; 44: 805-14.

7. Nissapatorn V, Lee C, Quek KF, Leong CL, Mahmud R, Abdullah KA. Toxoplasmosis in HIV/AIDS patients: a current situation. Jpn J Infect Dis 2004; 57: 160-5.

8. ŞenoğluS, YeşilbağZ, Altuntaş Aydın Ö, Kumbasar Karaosmanoğlu H, Kart Yaşar K. Toxoplasma gondii IgG Seroprevalence in Patients with HIV/AIDS. Turkiye Parazitol Derg 2018; 42: 175-9.

9. Aydın OA, Karaosmanoğlu HK, Korkusuz R, Nazlican O. Toxoplasma gondii IgG seroprevalence in HIV/AIDS patients Turkiye Parazitol Derg 2011; 35: 65-7

10. Rezanezhad H, Sayadi F, Shadmand E, et al. Seroprevalence of Toxoplasma gondii among HIV Patients in Jahrom, Southern Iran. Korean J Parasitol 2017; 55: 99-103.

11. Shen G, Wang X, Sun H, Gao Y. Seroprevalence of Toxoplasma gondii Infection among HIV/AIDS Patients in Eastern China. Korean J Parasitol 2016; 54: 93-6 
12. O'Bryan TA, Okulicz JF, Bradley WP, Ganesan A, Merritt SE, Agan BK. Toxoplasma gondii seroprevalence: 30-year trend in an HIV-infected US military cohort. Diagn Microbiol Infect Dis 2016; 84: 34-5.

13. Ayi I, Sowah AO, Blay EA, Suzuki T, Ohta N, Ayeh-Kumi PF. Toxoplasma gondii infections among pregnant women, children and HIV-seropositive persons in Accra, Ghana. Trop Med Health 2016; 44: 17.

14. Chemoh W, Sawangjaroen N, Siripaitoon P, et al. Toxoplasma gondii-prevalence and risk factors in HIV-infected patients from songklanagarind Hospital, Southern Thailand. Front Microbiol 2015; 6: 1304 .

15.Xavier GA, Cademartori BG, Cunha Filho NA, Farias NA. Evaluation of seroepidemiological toxoplasmosis in HIV/AIDS patients in the south of Brazil. Rev Inst Med Trop Sao Paulo 2013; 55: $25-30$

16. Safarpour H, Cevik M, Zarean M, et al. Global status of Toxoplasma gondii infection and associated risk factors in people living with HIV. AIDS 2020; 34: 469-74. doi: 10.1097/ QAD.0000000000002424. [Epub ahead of print].

17. Wang ZD, Wang SC, Liu HH, et al. Prevalence and burden of Toxoplasma gondii infection in HIV-infected people: a systematic review and meta-analysis. Lancet HIV 2017; 4: 177-88

18. Barratt JL, Harkness J, Marriott D, Ellis JT, Stark D. Importance of nonenteric protozoan infections in immunocompromised people. Clin Microbiol Rev 2010; 23: 795-836.

19.EACS European AIDS Clinical Society Guidelines 10.0, PART VI $105,2019$.

20.(https://www.eacsociety.org/guidelines/eacs-guidelines/eacsguidelines.html) Access date: 25.11.2019.

21. Guidelines for the prevention and treatment of opportunistic infections in adults and adolescents with HIV. (https://aidsinfo. nih.gov/guidelines/html/4/adult-and-adolescent-opportunisticinfection/322/toxoplasma-gondii) Access date: 01.10.2020.

22. Pozio E. Highly Active AntiRetroviral Therapy and opportunistic protozoan infections Parassitologia. 2004 ;46: 89-93.

23. Martin-Iguacel R, Ahlström MG, Touma M, et al. Incidence, presentation and outcome of toxoplasmosis in HIV infected in the combination antiretroviral therapy era. J Infect 2017; 75: 263-73. 